\title{
Swell and microstructural characteristics of high-plasticity clay blended with cement
}

\author{
S. J. Abbey ${ }^{1}$ (i) - E. U. Eyo ${ }^{2} \cdot$ S. $\mathrm{Ng}^{\prime} \mathrm{ambi}^{2}$
}

Received: 25 March 2019 / Accepted: 25 September 2019 / Published online: 5 December 2019

(C) The Author(s) 2019

\begin{abstract}
This study presents the effect of high plasticity on swell potential, swelling pressure and micro-structural characteristics of kaolinite-bentonite mixed clays. Five different mix ratios of kaolinite bentonite mixture of 100:0, 90:10, 75:25, 50:50 and $25: 75$ in $\%$ by weight of dry kaolinite were used. All five synthesised soils were then mixed with $0 \%, 5 \%$ and $8 \%$ of cement by weight of dry soil, cured for 28 days and subjected to the Atterberg limit, one-dimensional oedometer and scanning electron microscope test. The inclusion of $5 \%$ and $8 \%$ cement reduces the plasticity index of the treated soils as the percentage of bentonite increases. The effects on plasticity of treatment with $5 \%$ and $8 \%$ cement after a 28 -day curing period was evaluated, and the results show that reduction in plasticity index resulted in decreased swell potential and swelling pressure of the kaolinitebentonite mixed clays. The results of microstructural analysis of $5 \%$ cement-treated soils show formation of flocculated fabric and cementation of soil particles, and filling with cementitious compounds of the voids of flocculated fabric in the soil. The reduction in swell can be attributed to the resulting compacted and dense mass of treated soils due to cementation of soil particles and cation exchange. The complex swell behaviour of high-plasticity kaolinite-bentonite mix is explained using the onedimensional oedometer test, by further experimental study and examination of the microstructure of treated soils.
\end{abstract}

Keywords Plasticity index $\cdot$ Kaolinite-bentonite mix $\cdot$ Swell potential $\cdot$ Microstructure $\cdot$ Swell pressure $\cdot$ Swelling clay

\section{Introduction}

The extensive geological spread of swelling clays around the globe presents a key challenge to engineers, especially in areas where construction and land development activities are intended. Engineering structures intended for clay-rich soils of high plasticity would be at serious risk of failure if little or no solution is sought to salvage the foundation soil. What has become even more challenging nowadays is the continuous rise in world population and housing needs, thus making land development and construction activities on areas of weak or problematic soils unavoidable. High-plasticity soils have

\section{S. J. Abbey \\ Samuel.abbey@uwe.ac.uk}

1 Civil Engineering Cluster, Department of Geography and Environmental Management, Faculty of Engineering and Technology, University of the West of England, Bristol, UK

2 School of Energy, Construction and Environment, Faculty of Engineering, Environment and Computing, Coventry University, Coventry, UK continued to present geotechnical engineers with key challenges such as swelling and shrinkage due to their undesirable swelling and/or shrinkage characteristics. Soils with smectite clay minerals, such as montmorillonite, tend to swell during moisture ingress or shrink in extremely dry conditions, and are therefore termed swelling clays. The extensive geology of these soils has made them become practically unavoidable especially in areas where their deposits are very large (Nelson et al. 2015; Lin and Cerato 2012). Both man-made and periodic environmental factors work to trigger intrinsic mineral properties of expansive soil, with a resulting increase or decrease in the soil's volume (Nelson and Miller 1992). These soils are very problematic and almost impossible to compact during construction unless they are treated with cement or a combination of cement and other cementitious by-product materials (Abbey et al. 2015, 2016, 2017, 2018; Rahgozar et al. 2018; Ta'negonbadi and Noorzad 2017; Pourakbar et al. 2015). Soil stabilisation involves the improvement of the engineering properties of weak soils mechanically, physically or by mixing with binders to achieve some predetermined objectives. The use of additives to stabilise soils has been a major concern in the improvement of engineering characteristics of problematic soils 
such as soils susceptible to swelling (Kilic et al. 2016). Calciumbased hydraulic stabilising agents such as lime and cement are commonly used to chemically improve the engineering properties of highly plastic clays. The effect on soil of using lime and cement has been regarded as very similar in many respects (AlRawas et al. 2005), although cement-treated soils seem to have the least impact on the environment because of less chemical leaching, and they can provide greater sustainable strength for longer periods (Muhunthan and Sariosseiri 2008; Puppala et al. 2015). The strength properties of Portland cement (PC)-treated soils have been studied by several authors (Consoli et al. 2015; Caraşca 2016). Chen et al. (2016) examined the variation in strength of marine clay treated with cement during a wet deep mixing work at the Marina Bay Financial Centre in Singapore and found that the strength of the improved clay varied from $0.7 \mathrm{MPa}$ to about $5 \mathrm{MPa}$. In addition, according to Chen et al. (2016), the strength distribution in deep mixing-improved soils is affected by in situ soil properties and the chemical reactions between soil and cementitious constituent. The addition of either cement or lime to soils triggers a series of reactions including hydration, cation ionic exchange, flocculation and agglomeration and the production of pozzolanic reaction products (Nelson and Miller 1992). Soil stabilisation with cement is particularly desirable in terms of durability enhancement and provision of adequate resistance against cycles of freezing and thawing, which are common phenomena in cold climates. Just as in construction activities involving the use of concretes, cold weather can be regarded as one of the obstacles militating against soil stabilisation with cement, especially in temperate regions. One technical solution that can accommodate soil stabilisation during the cold weather season is the use of a high-early-strength cement. High-strength PC helps to counteract the effects of the cold conditions by increasing the early-stage heat of hydration. The presence of tricalcium sulphate $\left(\mathrm{C}_{3} \mathrm{~S}\right)$ added to the cement clinker during its production is what enhances the early strength development. Undoubtedly, cement-soil mixing techniques have been widely employed in the construction field for strength enhancement and improved compressibility (Farouk and Shahien 2013; Gaafer et al. 2015) and the beneficial outcome on the performance of cement-treated soils has been extensively documented in literature (Praticò and Puppala 2012; Åhnberg et al. 2001; Kitazume et al. 2015; Pakbaz and Alipour 2012). The application of cement in treatment of weak and problematic soils have resulted in improved performance such as reduction in plasticity and swell potential, substantial strength gain, increase in elastic modulus and resistance against the influence of moisture.

Bell (1993) suggested that cement addition up to $2 \%$ can modify soil properties, while much larger quantities could have a more considerable effect. Also, cement content may range from 3 to $16 \%$ of the soil's dry weight and depends on soil type and required properties. It was also stated elsewhere that the quantity of cement needed to stabilise expansive soils could range from 2 to $6 \%$ by dry weight of the soil (Chen
1975), and the higher the soil plasticity, the greater the quantity of cement to be used (PCA 1992). The American Association of State Highway Transportation Officials (AASHTO) cement requirement by dry weight for soils of high plasticity ranges from 9 to $15 \%$. The U.S. Army Corps of Engineers have recommended a range of 7-20\% of cement by dry weight of a silty or clayey soil. The seeming lack of a unified standard as to the quantity of cement required goes to show that stabilisation with cement does depend on several factors, not least the soil type and the field conditions encountered (Sarkar and Islam 2012). Few studies have evaluated the engineering behaviour of stabilised expansive soils by utilising some amount of different cement types to obtain an optimum proportion relying on several conditions (Sivapullaiah and Lakshmikanthay, 2010; Jamsawang et al. 2017; Cokca 2001; Latifi et al. 2015; Yilmaz and Civelekoglu 2009; Raftari et al. 2014; Kumar et al. 2014; Solanki et al. 2017; Kechouane and Nechnech 2015; Tilak et al. 2015; Consoli et al. 2010; Iravanian and Bilsel 2016; Abdelkader et al. 2013; Alrubaye et al. 2017; Asma Muhmed, 2013; Ghobadi et al. 2014). Geotechnical engineering design relying on assessment of the behaviour of clay-bentonite mixed soils treated with cement or other cementitious materials could find useful and broad application ranging from engineered clay barriers to subgrade construction materials (Wagner 2013; Lakshmikantha and Sivapullaiah 2006; Guler and Bozdey, 2001). However, few studies have focused on the determination of important engineering properties of kaolinite-bentonite mix modified by the addition of cement (Por et al. 2017; Jamsawang et al. 2017; Raftari et al. 2014). Therefore, the present study has investigated the swell and microstructural characteristics of highplasticity clay soils (kaolinite-bentonite mix) to evaluate and promote a better understanding of the geotechnical properties of these soils.

\section{Materials and methods}

\section{Materials and sample preparation}

High-plasticity clays occur in the UK and other part of the world, especially in many areas of the USA, and often offer the most economical material alternative for construction of highway embankments. Clay-rich soils are susceptible to swelling and shrinkage due to changes in moisture content and can result in subsidence due to shrink-swell action. Figure 1a and $\mathrm{b}$ shows areas that are susceptible to shrinkswell action in the UK and USA. For example, the geological clay formations (Woolwich and Reading beds, London, Gault, Weald, Kimmeridge, Oxford and Lias clays) found within the 
Fig. 1 a Shrink-swell potential map UK (Jones and Jefferson 2012). b Susceptibility of US soils to swelling (Olive et al. 1989)

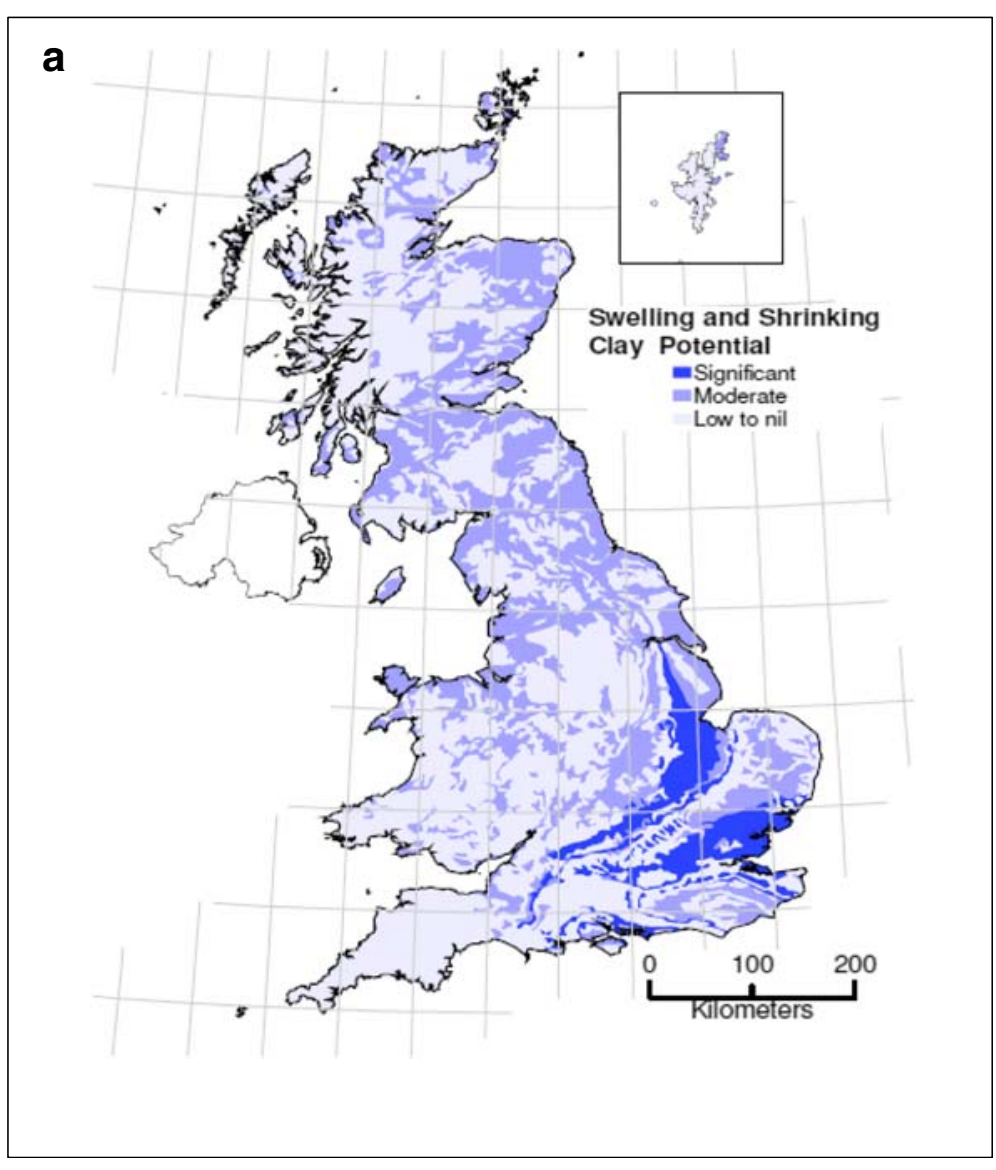

south-east area of England are particularly prone to shrinkswell and pose a higher risk of damage such as uplifting and cracking of lightly loaded, continuous-strip footings of foundations. Therefore, appropriate materials have been selected to enable remoulding and simulation of artificially made soils with engineering properties representing those of some naturally occurring clays (Horpibulsuk et al. 2011; Guney et al. 2007). The materials used in this study consisted of kaolinite $(\mathrm{K})$, sodium $(\mathrm{Na})$ montmorillonite bentonite clay $(\mathrm{B})$ and rapid-hardening cement ( $\mathrm{RHC}$ ). The $\mathrm{Na}$-montmorillonite bentonite is a clay of very high swelling potential as compared with kaolin clay, whose ability to swell is rather low. The kaolinite and Na-montmorillonite bentonite were sourced commercially from Mistral Industrial Chemicals in Northern Ireland, UK. The cement was supplied by Hanson Heidelberg Group, UK, and complies with BS EN 197-1 CEM I Portland cement. The cement is a low- $\mathrm{CO}_{2}$ cement produced using sustaining fuels and contains sufficiently highly recycled content. The RHC is suitable for fast-track construction projects in cold weather, because high early liberation of heat due to hydration can offset the retardation effect of low temperatures (AfriSam, 2017). For the purpose of generating relevant data input for this study, kaolinite and bentonite clays were mixed in five different ratios of 100:0, 90:10, 75:25, 50:50 and 25:75 in percentage by weight of dry kaolinite to produce five remoulded soils of varying plasticity index and with other engineering properties similar to that of some naturally occurring soils. The investigated soils were classified and compacted based on ASTM standard D 698 (2012) to ensure homogeneity and uniformity at optimum water content and maximum dry density. The five investigated soils, with varying plasticity index as obtained from the present study, are labelled soil 1 (S1), soil 2 (S2), up to soil 5 (S5), in order of increasing plasticity index, as shown in Table 1, and the properties of kaolinite, bentonite and cement are presented in Table 2.

The mix ratios of kaolinite and bentonite were selected to achieve artificially synthesised soils with a broad range of engineering properties due to variation in the chemical composition of kaolinite and bentonite (Eyo et al. 2019). Thereafter, all five synthesised soils were then mixed with $0 \%, 5 \%$ and $8 \%$ of cement by dry weight of soil, and compacted at optimum conditions following the procedure outlined in ASTM D 698 (2012). According to Cokca (2001), curing periods extending beyond 28 days may not be impractical, especially considering that results could be urgently needed for the planning of seasonal construction projects. Hence, in this study, curing periods of 7 and 28 days have been adopted. Therefore, soil-cement mixed samples were taken from the compaction mould using thin 


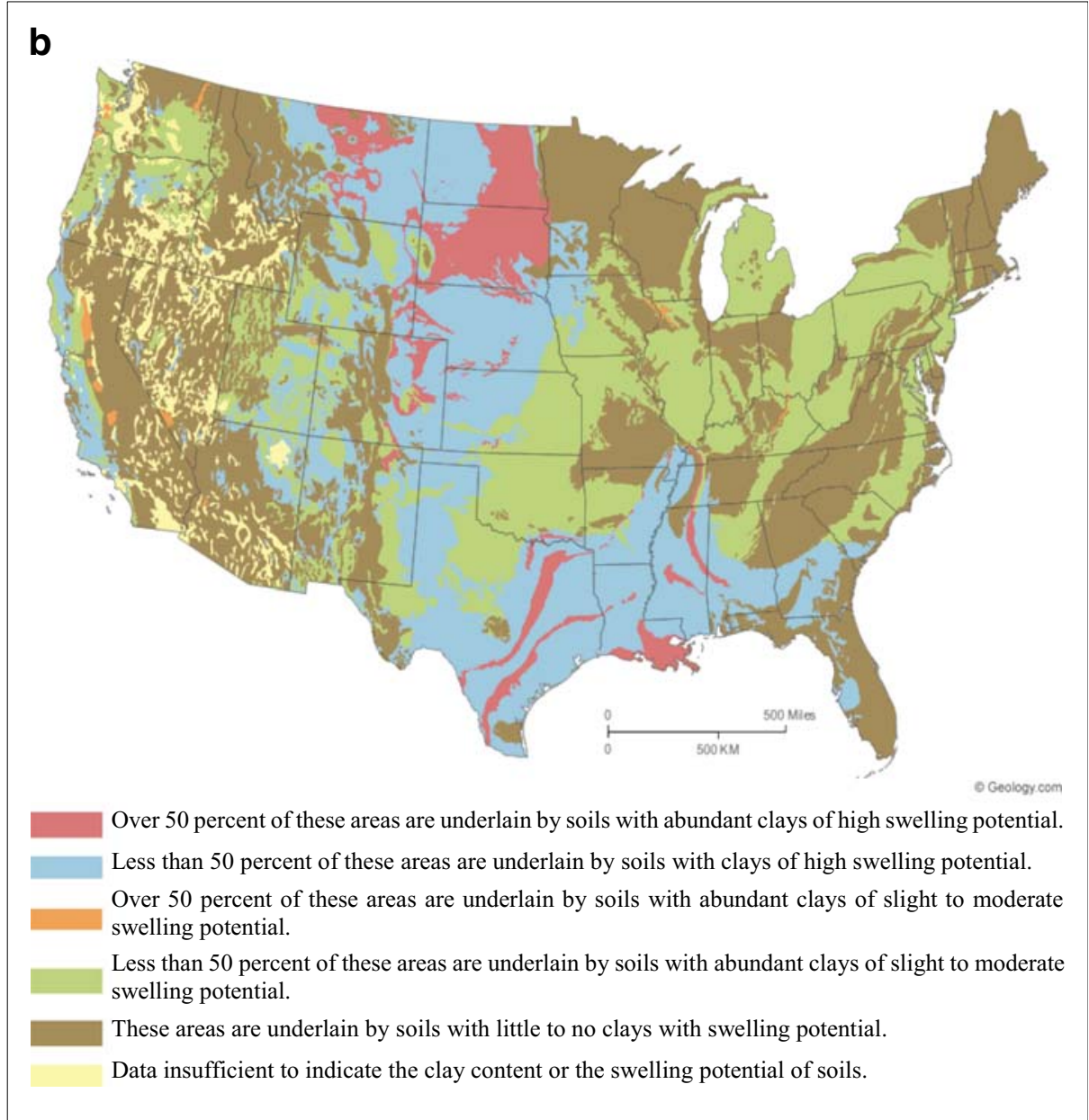

Fig. 1 (continued)

consolidation metal ring, and were rapped and cured for 7 and 28 days, respectively.

\section{Laboratory testing}

Both the untreated and cement-treated soils were subjected to a series of laboratory tests to obtain relevant soil parameters for the evaluation of swell and microstructural characteristics of the investigated clays. All samples were subjected to the Atterberg limits test following the procedure outlined in ASTM D 4318 (2011), as well as laser diffractometry, onedimensional oedometer and scanning electron microscope tests.

\section{Laser diffractometry}

A grain size distribution (GSD) test was performed using the Malvern Mastersizer 2000, which operates the Hydro 2000G module of sample dispersion based on laser diffraction technology for soil particle sizing, IS0 13320-1 (1999) and ASTM E1458 (1992). The Mastersizer 2000 is capable of analysing particles in the range of $0.02 \mu \mathrm{m}$ to $2000 \mu \mathrm{m}$. Since the sedimentation method of GSD is susceptible to inadequate dispersion of sample and fluctuations in suspension fluid viscosity, the Mastersizer 2000 thus addresses this issue directly. During measurement, particles passing through a focused laser beam scatter light at an angle inversely proportional to their size (Malvern 2007). A series of photosensitive detectors then measures the angular intensity of the scattered light, and following this, the map showing the scattering intensity versus angle becomes the primary source of information for calculating the particle size. In this study, the wet method of sample dispersion was used to study the particle size distribution for all five soil types. The soil samples in their powdered form were first dispersed into a non-reactive liquid and then fed into the system for particle size analysis. Following the analysis, parameters such as particle D-sizes were calculated by using the GRADISTAT (grain size distribution and statistics) version 4 spreadsheet program developed by Blott and Pye (2000), and the resulting size distribution curve is presented in Fig. 2. 
Table 1 Designation of the representative swelling clays and characterisation

\begin{tabular}{llllll}
\hline Property & \multicolumn{4}{l}{ Kaolinite-bentonite mix ratios } & \\
\cline { 2 - 6 } & $100 \% \mathrm{~K}: 0 \% \mathrm{~B}$ & $\begin{array}{l}90 \% \mathrm{~K}: 10 \% \mathrm{~B} \\
\mathrm{~S} 2\end{array}$ & $\begin{array}{l}75 \% \mathrm{~K}: 25 \% \mathrm{~B} \\
\mathrm{~S} 3\end{array}$ & $\begin{array}{l}50 \% \mathrm{~K}: 50 \% \mathrm{~B} \\
\mathrm{~S} 4\end{array}$ & $\begin{array}{l}25 \% \mathrm{~K}: 75 \% \mathrm{~B} \\
\mathrm{~S} 5\end{array}$ \\
\hline Liquid limit (\%) & 58 & 85 & 130 & 222 & 285 \\
Plastic limit (\%) & 30 & 37 & 48 & 58 & 72 \\
Plasticity index (\%) & 28 & 48 & 82 & 164 & 213 \\
Specific gravity & 2.60 & 2.65 & 2.69 & 2.70 & 2.76 \\
Silt content (\%) & 74 & 70 & 65 & 58 & 48 \\
Clay content (\%) & 26 & 30 & 35 & 42 & 52 \\
MDD (g/cm ${ }^{3}$ ) & 1.5 & 1.4 & 1.4 & 1.3 & 1.3 \\
OMC (\%) & 17 & 21 & 23 & 25 & 30 \\
USCS classification & $\mathrm{CL}$ & $\mathrm{CH}$ & $\mathrm{CH}$ & $\mathrm{CH}$ & $\mathrm{CH}$ \\
\hline
\end{tabular}

$M D D$ maximum dry density, OMC optimum moisture content, USCS Unified Soil Classification System

\section{Swell characteristics test}

One-dimensional swell strain and swell pressure tests were performed using the conventional one-dimensional oedometer test in accordance with ASTM standard D 4546 (2014) using distilled water. The specimen in the ring placed between two porous stones was subjected to a seating load of $5 \mathrm{kPa}$ with the automated linear variable displacement transducer (LVDT) set initially to zero. The test setup was then gradually inundated with water to maintain constant moisture content, and the samples were allowed to undergo vertical displacement for a minimum period of $24 \mathrm{~h}$. The swell potential was calculated as the ratio of the increase in specimen height $(\Delta \mathrm{H})$ from the original height $(\mathrm{H})$, expressed as a percentage. Following complete swelling of the samples, the load-back method of swell pressure testing was conducted on the specimens. The samples were gradually consolidated under increasing vertical

Table 2 Oxide composition of materials (\% by mass)

\begin{tabular}{llll}
\hline Oxide & \multicolumn{2}{l}{ Clay minerals (\%) } & \multicolumn{2}{l}{ RHC } \\
\cline { 2 - 3 } & Bentonite & Kaolinite & CEM I, 52.5R \\
\hline $\mathrm{SiO}_{2}$ & 57.1 & 49.0 & 20.7 \\
$\mathrm{Al}_{2} \mathrm{O}_{3}$ & 17.79 & 36 & 4.6 \\
$\mathrm{Fe}_{2} \mathrm{O}_{3}$ & 4.64 & 0.75 & 2.6 \\
$\mathrm{CaO}$ & 3.98 & 0.06 & 65.0 \\
$\mathrm{MgO}$ & 3.68 & 0.30 & 1.7 \\
$\mathrm{~K}_{2} \mathrm{O}$ & 0.9 & 1.85 & 0.4 \\
$\mathrm{TiO}_{2}$ & 0.77 & 0.02 & 0.3 \\
$\mathrm{Na}_{2} \mathrm{O}$ & 3.27 & 0.10 & 0.1 \\
$\mathrm{SO}_{3}$ & - & - & 2.9 \\
$\mathrm{Mn}_{2} \mathrm{O}_{3}$ & 0.06 & - & 0.1 \\
$\mathrm{LOI}$ & 7.85 & 12.0 & 2.9 \\
\hline
\end{tabular}

RHC rapid-hardening cement loads until the initial void ratio $\left(\mathrm{e}_{\mathrm{o}}\right)$ of each of the samples was achieved. The total pressure required to bring the specimens back to their original void ratio was used to determine the swell pressure.

\section{Scanning electron microscope (SEM)}

Microscopic examination and measurement of soil pores has gained much interest in recent years, partly because the analysis of images of soil fabric provides a straightforward investigation and analysis of soil void and porosity including clay particle degree of arrangement (Jha and Sivapullaiah 2015; Jamsawang et al. 2017). In this study, the microstructural characteristics of the investigated soils was studied using SEM to allow for microscopic examination and measurement of soil pores and orientation. Observations were made on dried and highly vacuumed samples using acceleration voltage of up to $17 \mathrm{kV}$ and working distance of about $20 \mathrm{~mm}$ at varying degrees of magnification. In order to examine the microstructural characteristics of the samples, scanning electron microscopy (SEM) was conducted on both the untreated and cementtreated soils to understand the effects of soil type and cementation on soil pores and orientation.

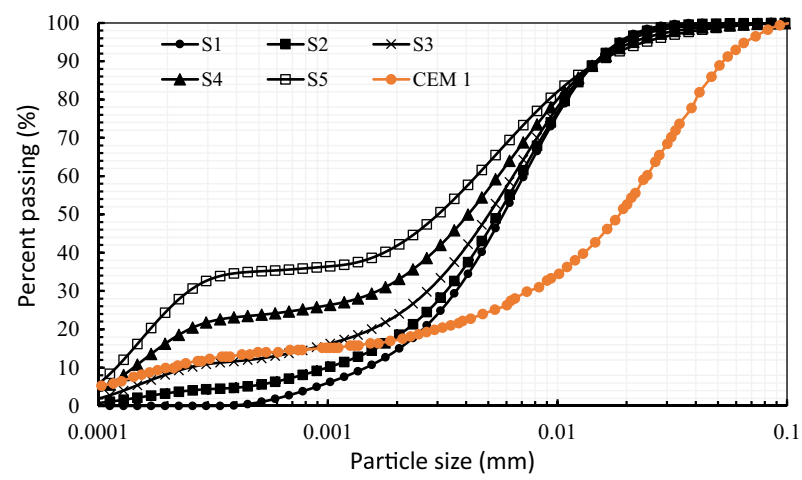

Fig. 2 Grain size distribution curve 


\section{Results and discussion}

\section{Particle size analysis and plasticity index}

The percentage of the retained sediments detected in each of the internal bins of the laser granulometer were inputted into the GRADISTAT program. This program uses the Method of Moments in Microsoft Visual Basic programming language to calculate the grain size parameters either arithmetically or geometrically (in microns) and in logarithm format (in phi units) (Krumbein and Pettijohn 1938). Figure 2 shows the grain size distribution of the swelling clay mixtures. Figure $3 a$ and $b$ shows a general increase in the Atterberg limit properties as the amount of bentonite increases. This is because bentonite contains more fines and is more clayey than the kaolin; hence the increased Atterberg limit properties are expected because more water is needed to make the mixture more plastic. On the other hand, the cement-modified kaolin shows a gradual increase in both liquid and plastic limits for the given percentages of the cement used, as shown in Fig. $3 \mathrm{~b}$. In this case, the increase in the liquid limit can be attributed to more water needed to make the cement-modified kaolin more fluid, whereas the increase in plastic limit suggests that the cement-kaolin mixture requires more water to change from its plastic state to a more semisolid state. There is, however, a reduction in the plasticity index of the kaolin clay-bentonite mixed soils blended with $5 \%$ and $8 \%$ cement, respectively, as

Fig. 3 a Atterberg limit of untreated soils. b Atterberg limit of cement treated soils shown in Fig. 3b. This is due to the cation exchange reactions and flocculation-aggregation as cement is being added. The extent of the reduction in plasticity index with the addition of cement to the kaolin-bentonite mixture is highly dependent on the percentage of bentonite and cement content present in the kaolin-bentonite mixed soils. From Fig. 3a and b, in soils S1, $\mathrm{S} 2$ and $\mathrm{S} 3$ with bentonite content less than $50 \%$ and blended with $5 \%$ cement, the difference in plasticity index is on the order of $1 \%, 6 \%$ and $3 \%$, and at $8 \%$ cement content is $4 \%$, $11 \%$ and $3 \%$. Soils S4 and S5 with $50 \%$ and $75 \%$ bentonite content show a difference in plasticity index of $32 \%$ and $2 \%$, respectively, at $5 \%$ cement content, and $22 \%$ and $3 \%$ at $8 \%$ cement content. This phenomenon can be attributed to the small amount of cement available to be used up by the mixture to enable cationic exchange and agglomeration of the mineral particles. Hence, an increase in the amount of the binder will be needed to cause a higher reduction in plasticity for the highly rich bentonite mixtures given their very high plasticity indices as brought about by the high montmorillonite content.

\section{Swell characteristics}

The oedometer test was conducted to observe changes in the vertical swell strains of the compacted expansive kaolinbentonite mixtures (S1, S2, S3, S4 and S5) under inundation with a seating load of $5 \mathrm{kpa}$ as presented in Fig. 4a. The analysis of the vertical swell strain results of the untreated soils

a

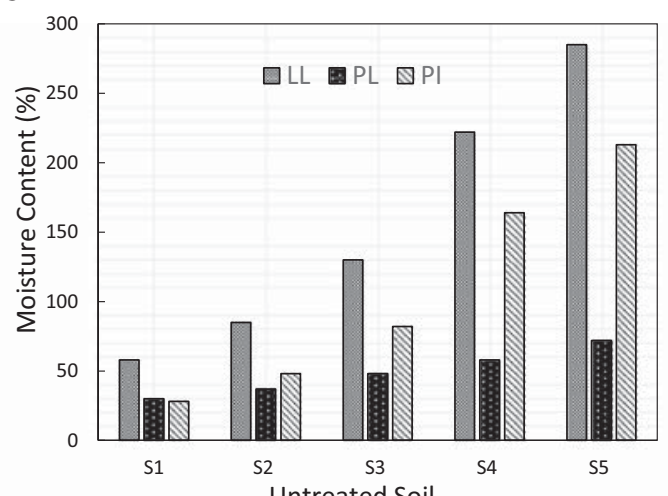

b

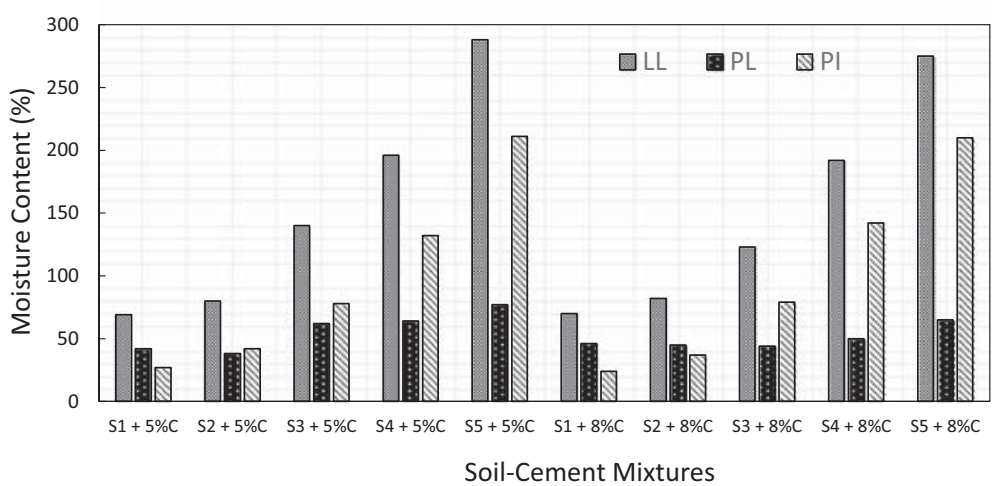



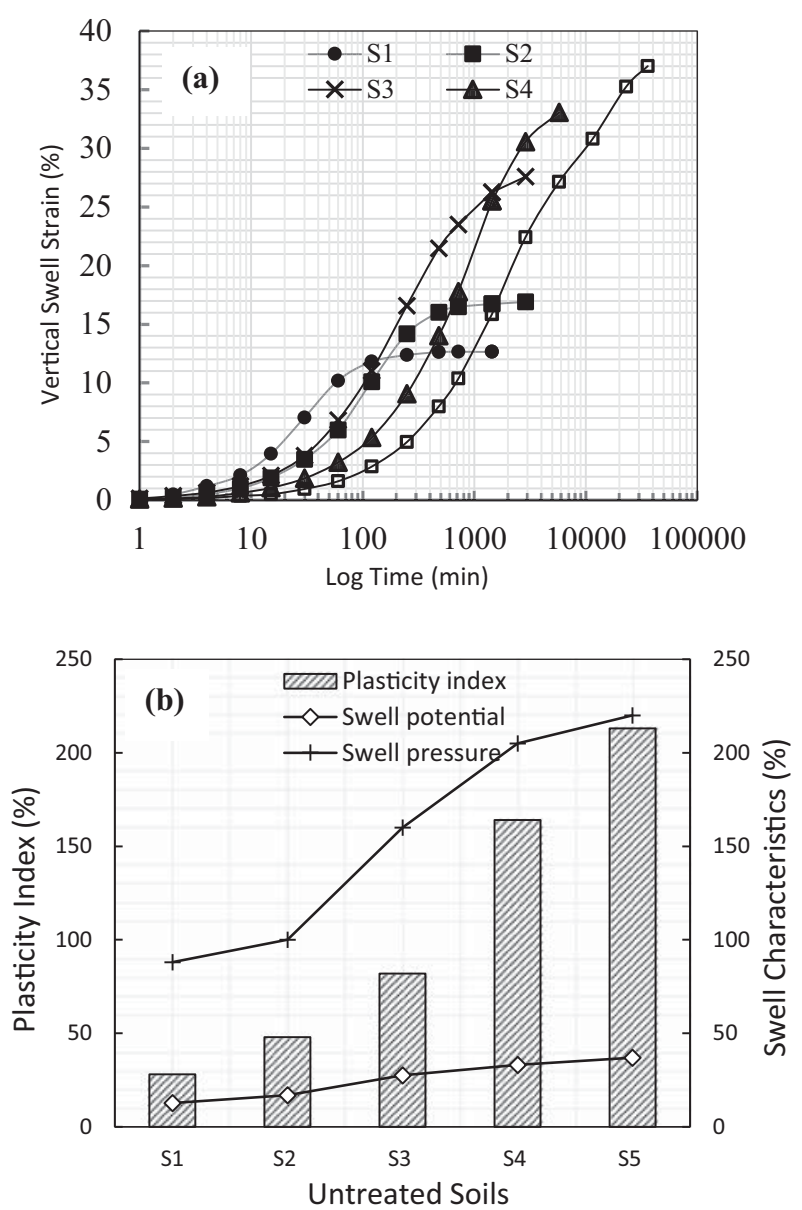

Fig. 4 a Vertical swell strain of untreated soils. b Variation of swell characteristics with plasticity

shows that an increase in the plasticity index causes an increase in maximum swelling strains due to the presence of high quantities of montmorillonite content in the swelling clays, as shown in Fig. 4a. Figure 4 b shows a plot of plasticity index versus swell characteristics (referred to as swell potential and swell pressure) for the investigated soils. From Fig. 4b it is clear that the increase in plasticity index also resulted in higher swelling pressures and an increase in the swelling potential of the untreated soils due to enlarged voids within the mass of the expanded soils, and hence higher pressure required to reduce voids. It is clear that the swell of the kaolinbentonite mix is mostly caused by the montmorillonite, which is a mineral present in larger quantities in the bentonite used. Both the swell potential and swell pressure increased by about $66 \%$, corresponding to an increase in bentonite in the range of $10-75 \%$ for the untreated kaolin-bentonite mixtures, as shown in Fig. 4b. This explains that an increase in percentage of bentonite increases the voids within the soil-bentonite mixtures, with the voids filled with air and water. Therefore, during water uptake, water is absorbed by the interlayer of montmorillonite, causing an increase in its volume, and after water uptake, voids are filled by the swollen montmorillonite within the bentonite, causing an increase in swell as the amount of montmorillonite minerals increases until the swelling pressure equals the vertical pressure. This is in line with the description of swelling mechanism of compacted bentonite as studied by Komine and Ogata (1996).

However, Fig. 5a-d indicates that the inclusion of 5\% and $8 \%$ cement reduces the maximum swell strain for all five investigated soils irrespective of the increase in plasticity index after 7 and 28 days of curing, due to the cementation effect and reduction in void spaces. Vertical swell strain reached stable peak values within approximately $2,8,24,50$ and $333 \mathrm{~h}$ with an increase in montmorillonite content of $0 \%$, $10 \%, 25 \%, 50 \%$ and $75 \%$ as present in soils S1, S2, S3, S4 and S5. Figure 5a-d shows that the kaolin-bentonite mixtures with higher percentage content of montmorillonite experienced prolonged swelling compared with the compacted kaolin-bentonite samples having lower quantities of montmorillonite. This is due to the higher water retention capacity of the samples rich in montmorillonite, which leads to a slower water infiltration rate in the sample, thus requiring longer time to reach an equilibrium swelling stage. It has been suggested that the rate of swelling at the primary stage (slope portion of the curves) could be a principal factor in the prediction of swell in relation to the hydraulic conductivity, since most of the soil swelling (about 90\%) occurs in this region (Güneyli 2017). In addition, the time to complete of this process could be very critical in the design of engineering structures for which backfill applications are required such as railways, motorways, and water and energy transmission lines.

Figure $6 \mathrm{a}$ and $\mathrm{b}$ shows that the inclusion of cement in the proportions of $5 \%$ and $8 \%$ by mass of dry kaolin-bentonite mix causes a significant reduction in swell potential and swell pressure after 7- and 28-day curing periods, irrespective of the plasticity of the kaolin-bentonite mixtures, compared with swell potential at day 0 . As could be observed, the greater reduction with significant elimination of the swell potential occurs after 28 days of curing for samples treated with 5\% and $8 \%$ cement as shown in Fig. 6a and b, respectively. However, it only required 7 days for the swelling potential to drop to almost zero when $8 \%$ cement was added, as shown in Fig. 6b, due to the higher cementation effect. This could also mean that the effect of curing diminishes, since there appears to be only a slight difference in swell potential for $8 \%$ cement addition after 7 and 28 days of curing based on the type of cement used, as discussed in previous sections. However, studies on the aging effects on swelling behaviour of soil-bentonite mixtures have shown that swelling potential may decrease with time due to the rearrangement of clay particles with time (Subba Rao and Tripathy, 2003; Delage et al. 2006). However, the results plotted in Fig. $6 \mathrm{c}$ and d show that swell pressure varies with the plasticity index of the cementtreated soils. The swell pressure reduces upon inclusion of 5\% and $8 \%$ cement after 7 and 28 days of curing compared with 
Fig. 5 a-d Vertical swell strain versus time for the treated soils after curing
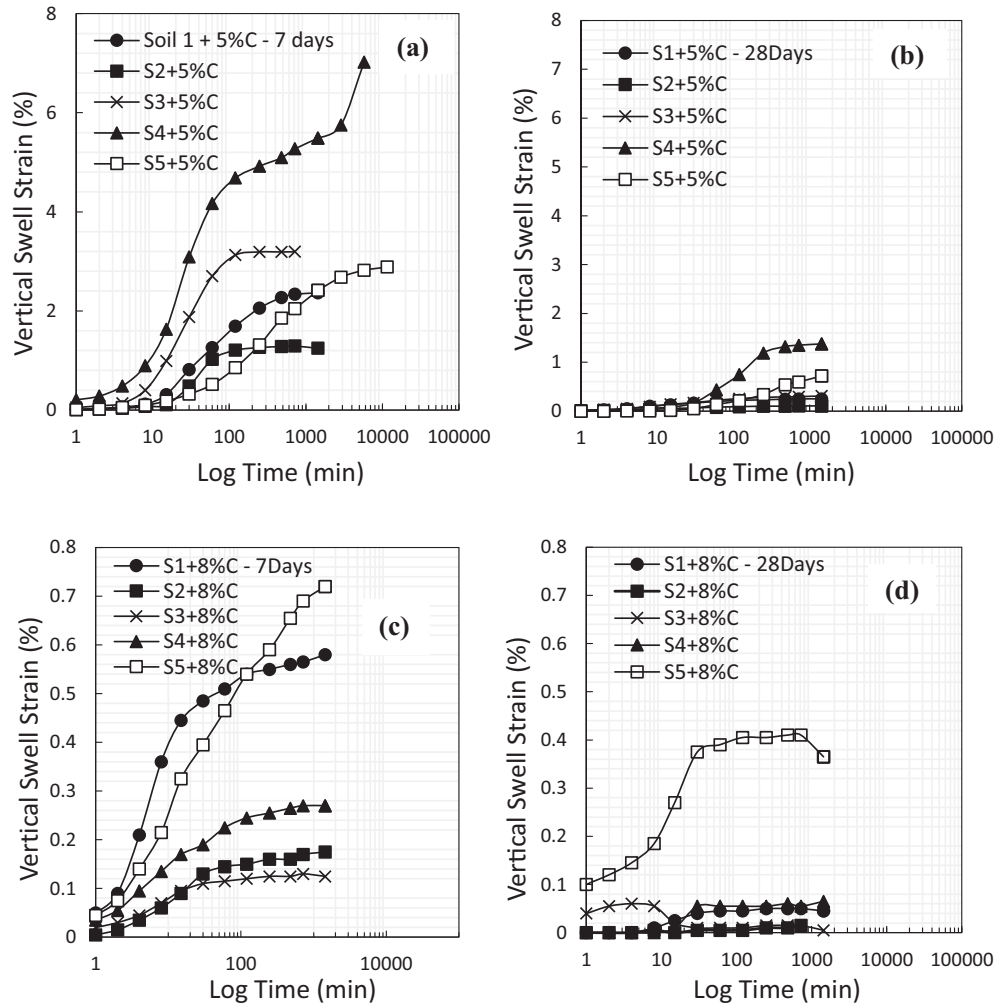

that of samples cured for 0 days, but variation is influenced by the soil plasticity index and increase in bentonite content from $\mathrm{S} 1$ to S5. The cementation effect reduces voids and causes a reduction in swell pressure depending on the amount of bentonite and cement content present in the cemented soilbentonite mixture, as shown in Fig. $6 \mathrm{c}$ and $\mathrm{d}$.

The reduction in both swell potential and swell pressure can be attributed to the formation of cementitious products of pozzolanic reaction, which tends to bind the aggregated and flocculated soil particles, thereby producing a stronger fabric.

\section{Microstructural analysis: SEM}

\section{SEM of untreated soils}

Microscopic examination was carried out to explain the mechanism of change in the compacted treated and non-treated
Fig. 6 a Variation of swell potential with plasticity for $5 \%$ cement inclusion. b Variation of swell potential with plasticity for $8 \%$ cement inclusion. c Variation of swell pressure with plasticity for $5 \%$ cement inclusion. $\mathbf{d}$ Variation of swell pressure with plasticity for $8 \%$ cement inclusion.
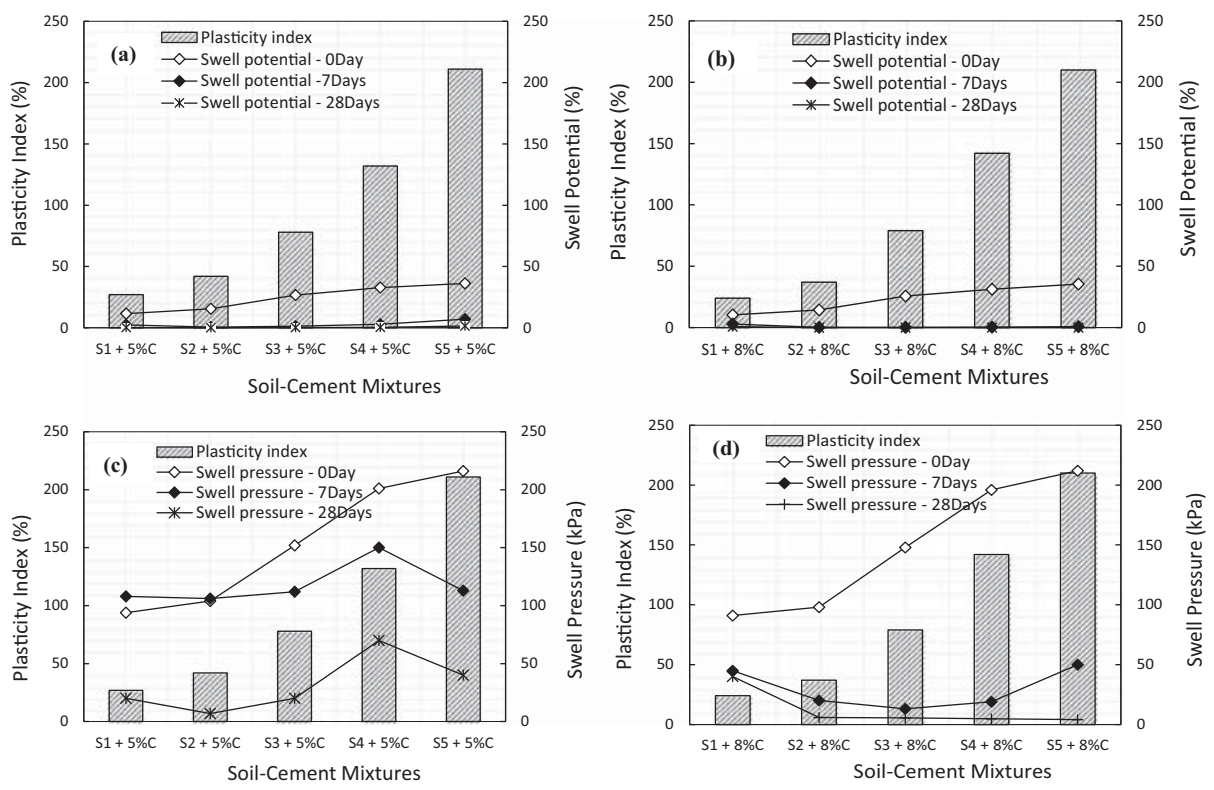
samples as well to support the rationale behind the outcome of the analyses of the engineering properties of the tested samples. SEM analysis is very important in understanding the behaviour of the investigated mixtures. Hence, SEM provides a perspective that supports the geotechnical behaviour and characteristic properties deduced from the tested mixes. This study presents the micrographs of the five compacted expansive kaolin-bentonite mixed clays. Figure $7 \mathrm{a}-\mathrm{e}$ reveals the pore and aggregate structure of the compacted swelling clays. These micrographs confirm that the micro-fabric of Namontmorillonite-rich clays is likely to be characterised by dispersed and undulating filmy particles as compared with the low-swelling kaolin-rich china clay with more of a leaf-like arrangement (Latifi et al. 2015). As the montmorillonite content in the kaolin-bentonite mix increases, the compacted mixtures tend to exhibit aggregated and concentrated clusters of clay particles. This behaviour gives rise to impervious layers, thus resulting in an initial low swelling rate at the primary swelling stage, but with the ultimate free swelling under inundation taking a longer time. This phenomenon also invariably suggests that as the kaolin content increases, the pore structure become more interlinked, resulting in a high permeability rate at the initial and primary stages and reduced swelling time when inundated.
Fig. 7 a SEM of kaolin clay-S1. b SEM of kaolin-bentonite mixS2. c SEM of kaolin-bentonite mix -S3. d SEM of kaolinbentonite mix - S4. e SEM of kaolin-bentonite mix - S5.
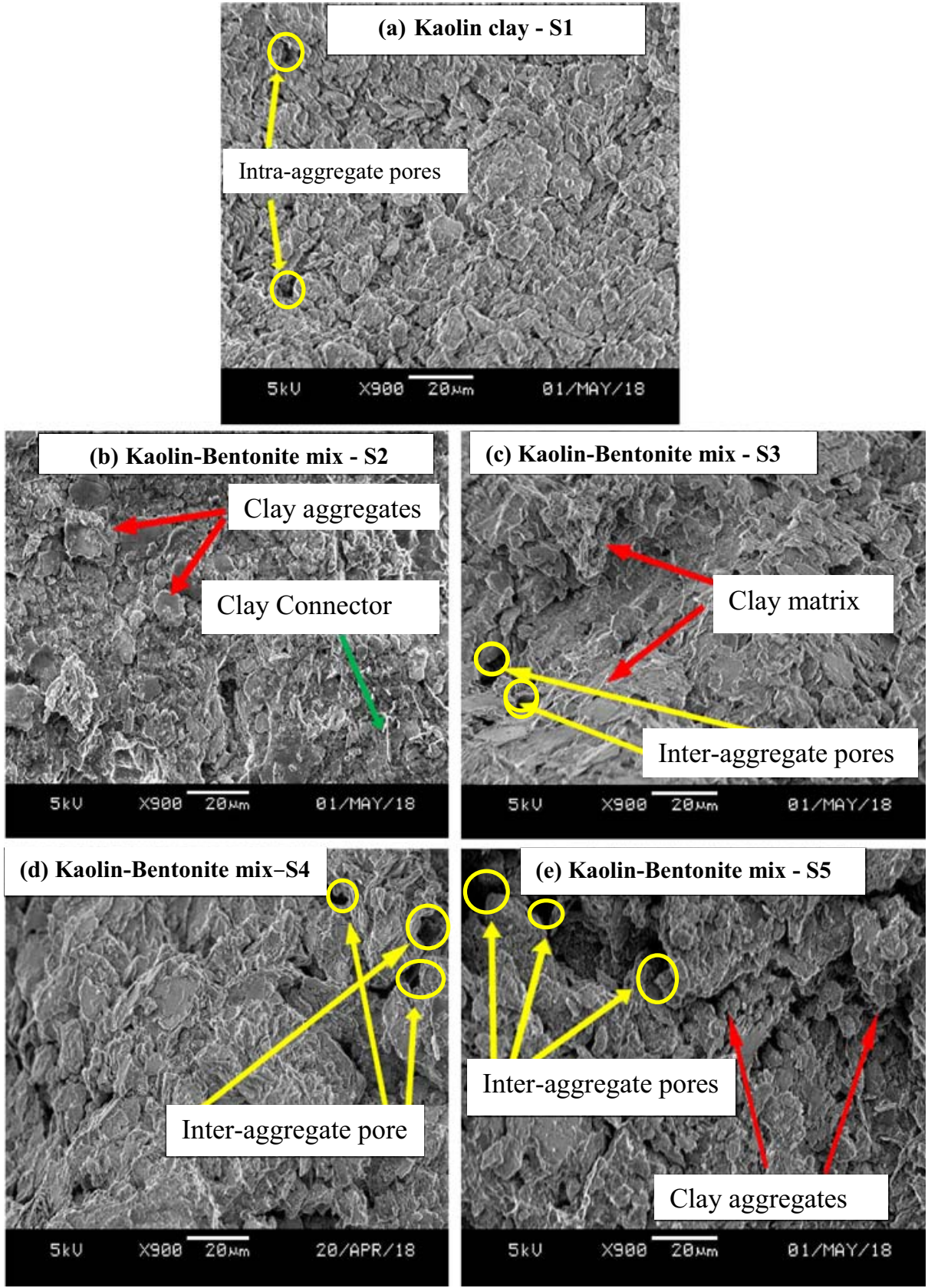


\section{SEM of treated soils}

Given that most of the engineering properties studied showed little variation in the curing duration between the kaolinbentonite-cement mixes studied, the SEM micrographs are only provided for $5 \%$ cement-treated samples cured at 28 days. From Fig. $8 \mathrm{f}-\mathrm{j}$, the structure of the treated mixes containing $50 \%$ and $75 \%$ bentonite are similar and very closely in agreement with the findings according to Lee et al. (2001), and it was proposed that a 50:50 mix ratio of bentonitekaolinite clay could be a threshold mix for an effective barrier in strong acidic and alkaline environments but not in a calcium chloride-enriched environment. A general trend in the SEM for the stabilised samples is the formation of larger clusters for mixes with lower amounts of bentonite, thus showing the high influence of the cement on the mixes as the amount of bentonite
Fig. 8 f SEM of S1 mixed with $5 \%$ cement. g SEM of S2 mixed with 5\% cement. h SEM of S3 mixed with $5 \%$ cement. i SEM of S4 mixed with 5\% cement. j SEM of S5 mixed with 5\% cement.
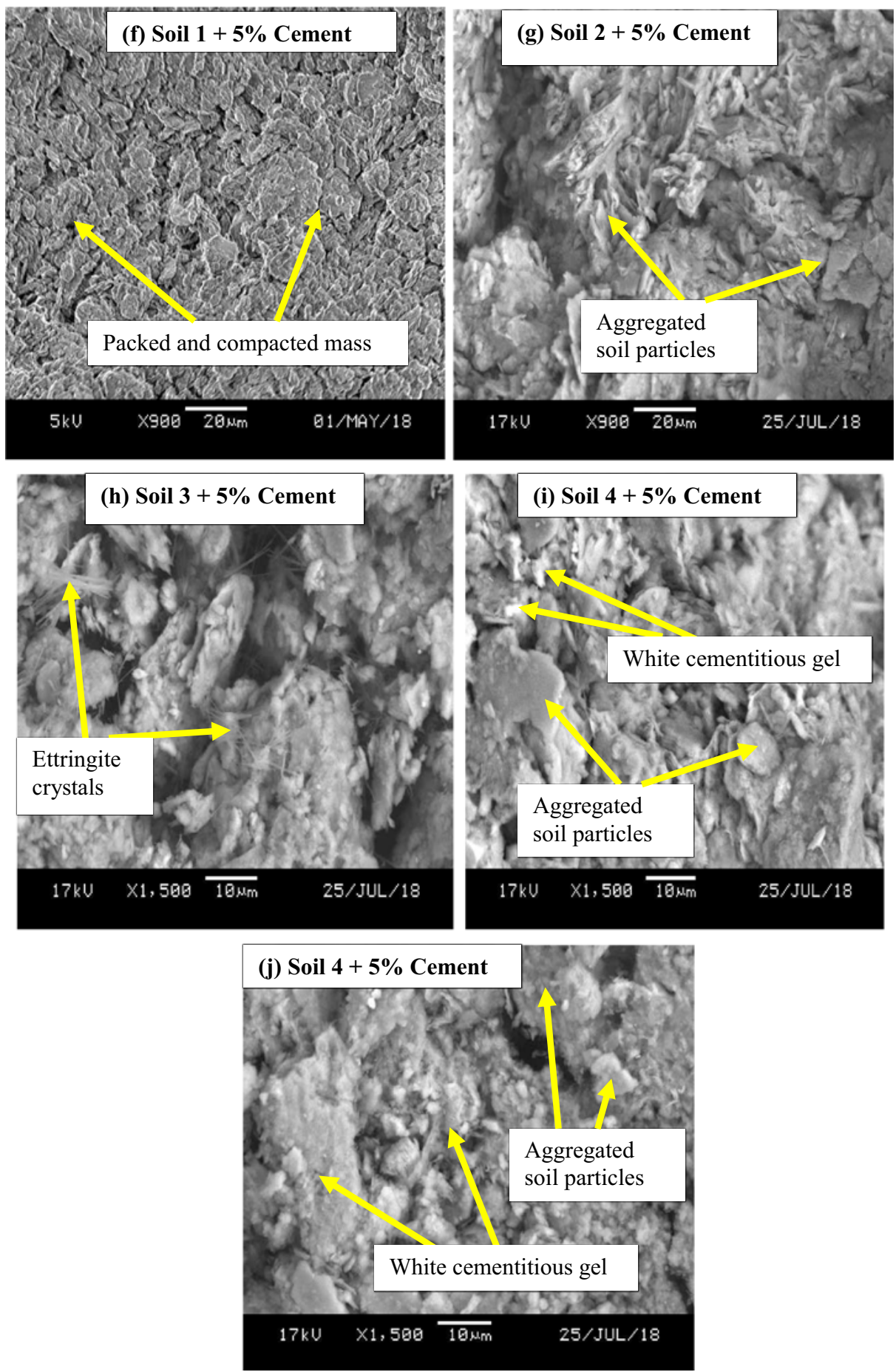
decreases. Several aggregated soil particles of varying shapes and sizes are observed with the addition of $5 \%$ cement. There are formations of needle-like structures, which continually develop over time to fill up the visible pore holes within the treated soils. This results in a more compacted treated mass with reduced voids. The formation of the white cementitious gel can be attributed to the development of a cementitious compound, calcium silicate hydrate (CSH gel), during the hydration of cement. This increases the bonding between particles, closing up and filling pores and leading to the formation of more closely packed soils with low swell potential. According to Jha and Sivapullaiah (2015), the binding and coating of aggregated soil particles leads to the formation of a densely packed and compacted structure, where relatively few white patches are observed, reflecting the consumption of cementitious gel in filling and binding of particles.

\section{Conclusion}

This study has considered the swelling mechanism and microstructural characteristics of five expansive kaolin-bentonite mixed clays of high plasticity. The complex swell behaviour has been explained using the Atterberg limit test, onedimensional oedometer test and scanning electron microscope (SEM) test, and the following conclusions have been drawn.

- Conventional one-dimensional oedometer tests conducted on the untreated samples under inundation revealed a progressive increase in the amount of swelling with increased montmorillonite content.

- The kaolin-bentonite mixtures with higher amounts of montmorillonite experience prolonged swelling compared with the compacted kaolin-bentonite samples with lower amounts of montmorillonite, due to the higher water retention capacity of the samples rich in montmorillonite, leading to a lower rate of water intake.

- The inclusion of $5 \%$ and $8 \%$ cement reduced the maximum swell strain for all five investigated soils, irrespective of plasticity index, after 7 and 28 days of curing due to the cementation effect and reduction in void spaces.

- The pore voids of the compacted clays obtained from SEM analysis show the presence of a large amount of inter-aggregate pores as compared with the interaggregate pore sizes as the plasticity increased.

- The formation of the white cementitious gel is due to the development of calcium silicate hydrate (CSH gel) formed during cement hydration, and this increases the bonding between particles, leading to the reduction in swell potential and swell pressure.

Open Access This article is distributed under the terms of the Creative Commons Attribution 4.0 International License (http:// creativecommons.org/licenses/by/4.0/), which permits unrestricted use, distribution, and reproduction in any medium, provided you give appropriate credit to the original author(s) and the source, provide a link to the Creative Commons license, and indicate if changes were made.

\section{References}

Abbey SJ, Ngambi S, Ngekpe BE (2015) Understanding the performance of deep mixed column improved soils - a review. International Journal of Civil Engineering and Technology 6(3):97-117

Abbey SJ, Ngambi S, Coakley E (2016) Effect of cement and by-product material inclusion on plasticity of deep mixing improved soils. International Journal of Civil Engineering and Technology 7(5): 265-274

Abbey SJ, Ngambi S, Ganjian E (2017) Development of strength models for prediction of unconfined compressive strength of cement/byproduct material improved soils. Geotech Test J 40(6):928-935

Abbey SJ, Ngambi S, Olubanwo AO, Tetteh FK (2018) Strength and hydraulic conductivity of cement and by-product cementitious materials improved soil. Int J Appl Eng Res 13(10):8684-8694

Abdelkader Z, Belkacem L, Vipulanandan C (2013) Effect of cementitious materials on the performance of clayey soils. Symposium International sur la construction en zones sismiques (SICZS2013) Chlef les 9 et 10 Octobre 2013 EFFECTS, pp 495-503

AfriSam Technical Reference Guide $8^{\text {th }}$ Edition (2017) pp 1-162. ISBN No. 978-0-620-50534-5

Åhnberg H, Bengtsson PE, Holm G (2001) Effect of initial loading on the strength of stabilised peat. Proceedings of the Institution of Civil Engineers - Ground Improvement 5(1):35-40

Al-Rawas AA, Hago AW, Al-Sarmi H (2005) Effect of lime, cement and sarooj (artificial pozzolan) on the swelling potential of an expansive soil from Oman. Build Environ 40(5):681-687

Alrubaye AJ, Hasan M, Fattah MY (2017) Stabilization of soft kaolin clay with silica fume and lime. Int J Geotech Eng 11(1):90-96

Asma Muhmed AM (2013) Effect of lime stabilisation on the strength and microstructure of clay. IOSR Journal of Mechanical and Civil Engineering 6(3):87-94

ASTM International (1992) E1458-92. Standard Test Method for Calibration Verification of Laser Diffraction Particle Sizing Instruments Using Photomask Reticles, ASTM International, West Conshohocken, PA, 2001

ASTM International (2011) ASTM D4318-11. Standard test methods for liquid limit, plastic limit, and plasticity index of soils. ASTM International

ASTM International (2012) ASTM D698-12. Standard test methods for laboratory compaction characteristics of soil using standard effort. ASTM International

ASTM International (2014) ASTM D4546-14. Standard test methods for one-dimensional swell or collapse of soils. ASTM International

Bell FG (1993) Engineering treatment of soils, E \& FN Spon, Taylor \& Francis Group

Blott S, Pye K (2000) A grain size distribution and statistics package for the analysis of unconsolidated sediments. Earth Surf Proc Landforms 26:1237-1248

Carașca O (2016) Soil improvement by mixing: techniques and performances. Energy Procedia 85:85-92

Chen FH (1975) Foundations on expansive soils. Elsevier, New York

Chen EJ, Liu Y, Lee F (2016) A statistical model for the unconfined compressive strength of deep-mixed columns. Géotechnique 66(5):351-365

Cokca E (2001) Use of class C fly ashes for the stabilization of an expansive soil. J Geotech Geoenviron 127(7):568-573 
Consoli NC, Heineck KS, Carraro JAH (2010) Portland cement stabilization of soil-bentonite for vertical cutoff walls against diesel oil contaminant. Geotech Geol Eng 28(4):361-371

Consoli NC, Winter D, Rilho AS, Festugato L, Teixeira BS (2015) A testing procedure for predicting strength in artificially cemented soft soils. Eng Geol 195:327-334

Delage P, Marcial D, Cui YJ, Ruiz X (2006) Ageing effects in a compacted bentonite: a microstructure approach. Geotechnique 56(5):291-304

Eyo EU, Ngambi S, Abbey SJ (2019) Effect of intrinsic microscopic properties and suction on swell characteristics of compacted expansive clays. Transportation Geotechnics 18:124-131

Farouk A, Shahien MM (2013) Ground improvement using soil-cement columns: experimental investigation. Alexandria Engineering Journal 52(4):733-740

Gaafer M, Bassioni H, Mostafa T (2015) Soil Improvement Techniques. International Journal of Scientific \& Engineering Research 6(12): 217-222

Ghobadi MH, Abdilor Y, Babazadeh R (2014) Stabilization of clay soils using lime and effect of $\mathrm{pH}$ variations on shear strength parameters. Bull Eng Geol Environ 73(2):611-619

Guler E, Bozdey I (2001) Effect of lime and compaction energy on hydraulic conductivity of clay liners. Proceeding of the 15 th International Conference on soil mechanics and geotechnical Engineering Istambul, 3, pp 1963-1966

Guney Y, Sari D, Cetin M, Tuncan M (2007) Impact of cyclic wettingdrying on swelling behavior of lime-stabilized soil. Build Environ 42(2):681-688

Güneyli H (2017) Assessments of the hydraulic conductivity for predicting the swelling characteristics of compacted soils. Acta Geotechnica Slovenica 14(1):11-27

Horpibulsuk S, Yangsukkaseam N, Chinkulkijniwat A, Du YJ (2011) Compressibility and permeability of Bangkok clay compared with kaolinite and bentonite. Appl Clay Sci 52(2):150-159

Iravanian A, Bilsel H (2016) Tensile strength properties of sand-bentonite mixtures enhanced with cement. Procedia Engineering 143:111-118

ISO 13320-1:1999(E), Particle size analysis-LASER diffraction methods - Part 1: general principles

Jamsawang P, Nuansrithong N, Voottipruex P, Songpiriyakij S, Jongpradist $P$ (2017) Laboratory investigations on the swelling behavior of composite expansive clays stabilized with shallow and deep clay-cement mixing methods. Appl Clay Sci 148:83-94

Jha AK, Sivapullaiah PV (2015) Mechanism of improvement in the strength and volume change behavior of lime stabilized soil. Eng Geol 198:53-64

Jones LD, Ian J (2012) Expansive soils. In: John B, Tim C, Hilary S, Michael B (eds) ICE manual of geotechnical engineering, volume I. ICE manuals, pp. 1-29

Kechouane Z, Nechnech A (2015) Characterization of an expansive clay treated with lime: effect of compaction on the swelling pressure. AIP Conference Proceedings 1653(1):020057-020058

Kilic R, Kucukali O, Ulamis K (2016) Stabilisation of high plasticity clay with lime and gypsum. Bull Eng Geol Environ 75(2):735-744

Kitazume M, Grisolia M, Leder E, Marzano IP, Antonio AS, Correiac PJ, Oliveira PJV, Åhnbergd H, Andersson M (2015) Applicability of molding procedures in laboratory mix tests for quality control and assurance of the deep mixing method. Soils Found 55(4):761-777

Komine H, Ogata N (1996) Prediction for swelling characteristics of compacted bentonite. Can Geotech J 33(1):11-22

Krumbein WC, Pettijohn FJ (1938) Manual of sedimentary petrography. Crofts, New York

Kumar S, Dutta RK, Mohanty B (2014) Engineering properties of bentonite modified with lime and gypsum. Jordan Journal of Civil Engineering 8(2):199-215
Lakshmikantha H, Sivapullaiah PV (2006) Relative performance of lime stabilized amended clay liners in different pore fluids. Geotech Geol Eng 24(5):1425-1448

Latifi N, Rashid ASA, Siddiqua S, Horpibulsuk S (2015) Micro-structural analysis of strength development in low- and high swelling clays stabilized with magnesium chloride solution - a green soil stabilizer. Appl Clay Sci 118:195-206

Lee SL, Sinha AN, Aolinite B (2001) Bentonite:kaolinite clay liner Geosynth Int 8(2):113-133

Lin B, Cerato AB (2012) Prediction of expansive soil swelling based on four micro-scale properties. Bull Eng Geol Environ 71(1):71-78

Malvern (2007) Mastersizer 2000 essentials user manual. Worcestershire, UK

Muhunthan B, Sariosseiri F (2008) Interpretation of geotechnical properties of cement treated soils. Washington DOT

Nelson JD, Miller DJ (1992) Expansive soils: problems and practice in foundation and pavement engineering. Wiley, New York

Nelson JD, Chao KC, Overton DD, Nelson EJ (2015) Foundation engineering for expansive soils. Hoboken New Jersey

Olive W, Chleborad A, Frahme C, Shlocker J, Schneider R, Schuster R (1989) Swelling clays map of the conterminous United States Map I-1940. USGS Miscellaneous Investigations Series 1989. https:// geology.com/articles/expansive-soil.shtml. Accessed 31 July 2019

Pakbaz MS, Alipour R (2012) Influence of cement addition on the geotechnical properties of an Iranian clay. Appl Clay Sci 67-68:1-4

PCA (1992) Soil cement laboratory handbook. Portland Cement Association, Skokie

Por S, Nishimura S, Likitlersuang S (2017) Deformation characteristics and stress responses of cement-treated swelling clay under con fined one-dimensional swelling. Appl Clay Sci 146:316-324

Pourakbar S, Asadi A, Huat BBK, Fasihnikoutalab MH (2015) Stabilization of clayey soil using ultrafine palm oil fuel ash (POFA) and cement. Transportation Geotechnics 3:24-35

Praticò FG, Puppala AJ (2012) Lime and cement treatments of subgrades in southern Italy: facing interports issues and challenges. Procedia Social and Behavioral Sciences 53 pp.389-398. http://www. sciencedirect.com/science/article/pii/S1877042812043522. Accessed 31 July 2019

Puppala AJ, Pedarla A, Bheemasetti T (2015) Soil modification by admixtures: concepts and field applications, Elsevier Ltd. https://www. sciencedirect.com/science/article/pii/B9780081001912000101. Accessed 31 July 2019

Raftari M, Rashid ASA, Kassim KA, Moayedi H (2014) Evaluation of kaolin slurry properties treated with cement. Measurement: Journal of the International Measurement Confederation 50(1):222-228

Rahgozar MA, Saberian M, Li J (2018) Soil stabilization with nonconventional eco-friendly agricultural waste materials: an experimental study. Transportation Geotechnics 14:52-60

Sarkar G, Islam M (2012) Study on the geotechnical properties of cement based composite fine-grained soil. International Journal of Advanced Structures and Geotechnical Engineering 1(2):42-49

Sivapullaiah PV, Lakshmikanthay H (2010) Lime-stabilised illite as a liner. Proceedings of the Institution of Civil Engineers Ground Improvement 9(1):39-45

Solanki D, Dave M, Maheshwari A (2017) Engineering properties of Bentonite stabilized with admixture ( rubber Tyre chips ) pp. 21067-21071

Subba Rao KS, Tripathy S (2003) Effect of aging on swelling and swellshrink behaviour of a compacted expansive soil. ASTM Geotechnical Testing Journal 26(1):36-46

Ta'negonbadi B, Noorzad R (2017) Stabilization of clayey soil using lignosulfonate. Transportation Geotechnics 12:45-55

Tilak BV, Dutta RK, Mohanty B (2015) Strength characteristics of bentonite-lime-gypsum mix reinforced with coir fibres. Eur J Environ Civ Eng 19(9):1108-1135 